\title{
AN ANALYSIS OF THE STUDENTS PREPOSITION ERRORS IN WRITING RECOUNT TEXT AT ENGLISH DEPARTMENT IN ACADEMIC YEAR 2013/2014 AT IAIN IMAM BONJOL PADANG
}

\author{
*Vivi Zurniati \\ English Language Education Program, Graduate Program \\ Universitas Negeri Padang, Indonesia \\ Email: vivi_zurniati@gmail.com \\ *Corresponding Author, Received: November 12, 2018, Revised: December 10, 2018, Accepted: December 21, 2018
}

\begin{abstract}
Preposition is one of language elements that plays an important role to join the words to build sentences. However, the errors of using it keep occurring in the sixth semester students writing compositions. This research was conducted to find out and analyzed the errors on using preposition that occur in the students writing of recount essay. This research was classified into descriptive one. This research was about the errors of preposition used in the recount essay done by the sixth semester students of English Department of IAIN Imam Bonjol Padang. The data of this research were the incorrect preposition found in the recount essay written by the students. The data were collected through giving the students a writing test of recount test. In order to know the causes of the errors, the data were collected by doing the interview. This research investigated about the types of errors and which type that mostly occurs of preposition used in the writing of recount essay and what are the causes. The findings show that the students made some errors on the use of preposition. They are within the category of interlingual; features of L1 are transferred to the target language, and intralingual; ommission, addition, misselection of FL preposition, and redundancy. These types are based on Corder. Meanwhile, the interview guideline is derived from Richards theory of causes of errors. The cause of error in using English preposition is the ignorance of the rule restriction that the students perform in doing the writing activity. To conclude, the error in using English preposition is because of the students low of grammatical ability.
\end{abstract}

Keywords: Preposition Error, Writing Recount Text

\section{INTRODUCTION}

The study of preposition has been performed by numbers of grammarians for more than centuries as one of linguistic branches among some large amounts to 


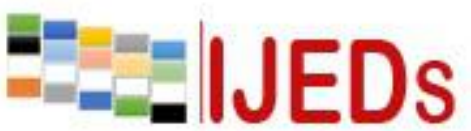

http://ijeds.ppj.unp.ac.id/index.php/IJEDS

constitute the unity of English composition. This point undertakes above one circumstance in which the preposition own its site from some grammatical elements of English comprises in one unity as one language system. This point becomes the reason why the use of the preposition is an important aspect of languages. Mackova (2012) has also stated this one in which she explains that the basic information of the usage of prepositions along with the characteristics of prepositions as a word class can usually be found in every grammar of English.

Dealing with what has been asserted above, as preposition is one of the grammar parts, writing is one among several skills of English which requires greater efforts in producing a perfect outcome because it will be printed or got published. It differs from the speaking activity where it is a direct and rapid activity. Therefore, all writing components i.e. contents, organization, vocabulary, language use, and mechanic (Ghanbari et al. 2012), should hindrance any type of mistakes.

Related to the previous issue, the use of preposition is one of the components of writing-language use-supposed not to carry any mistakes. Therefore, the writing product should be made properly. Regarding to the issue of error in using English preposition. Nonkukhetkhong (2013), shares his mind about the concept of grammatical error analysis. He describes that making errors is common, especially grammatical errors as it is regarded as a part of learning a second language or a foreign language. Therefore, as long as the final aim is to see the students real grammatical condition, the error analysis study is ultimately needed.

Furthermore, City (2003) states about the definition of preposition. She sees that they tell the "position" of people or things in relation to where other people or things are located. They can show relationships between objects in space (where one thing is in relation to another), and they can show relationships in time (when an event occurred in relation to another event). This theory is closely meaning to one of the organizational structures of the recount text. In writing the recount text, Nafisah and Kurniawan in Nurohmah (2013) state that the students must retell the sequence of events or experiences which they have ever got in the past. Thus, the use of preposition is needed in constructing the recount text. In other words, the use of preposition in 


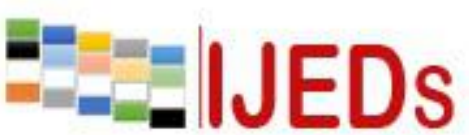

http://ijeds.ppj.unp.ac.id/index.php/IJEDS
International Journal of Educational Dynamics

Vol. 1 No. 1 (pp. 55-68) December 2018

p_ISSN 2655-4852

e ISSN 2655-5093

writing the genre of recount is crucial in order to be able to show some particular elements of the text.

Moreover about preposition and writing up a recount text, it is a text we use when we want to tell what happened and msoetimes to teach a lesson (Rajan et al.2002). At the same time, he also states about three points below in which all of their parts constitute a recount text; they are orientation, series of events, and personal reaction to the events. Moreover, this type of text also consists of some language features. The first one is specific participants, past tense of verbs, action verbs, connectors of time, detail about matters participants' words, the first person.

In addition, related to the use of preposition and constructing the recount text, it plays an important role in composing the recount text. This one is due to the use of preposition is one the organizational structures and one of language features of a recount text. In organizational structure, the preposition is used to construct the second part that is the series of event. In that series of event, in the language feature, preposition is used as the connectors of event, such as on Wednesday and at the same time. Therefore, the use of preposition is needed to tell the event happened.

Dealing with the above point, the grammatical error analysis is important to be done in order to know the errors that the students make in using preposition especially in writing recount text. Based on the curriculum which is being implemented, writing is one of the compulsory subjects the students should get at State Institute for Islamic Study Imam Bonjol Padang. Related to the above curriculum, some subjects such as Structures and Writings had been given to the fifth semester students.

\section{METHOD}

As the purpose of the research is to find the types of preposition error, which type that appear most frequently, and what cause the error. As the first instrument the writing test was analyzed through reading the students writing. After doing so, the sentences that carry prepositions errors were marked as the data to be presented in the findings. Then, those wrong prepositions using was determined by the researcher then recorrected and analyzed based on the theory from Lindstromberg (2010) to see the rule 


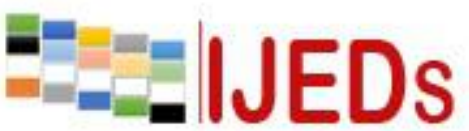

http://ijeds.ppj.unp.ac.id/index.php/IJEDS

of prepositions use. His theory was the basic consideration for the researcher to state the preposition use is correct or incorrect. After the determination, the incorrect preposition use explained by showing the correct forms followed by the explanation of the correct preposition. The causes of error in using the English prepositions were obtained from the answers the students gave during the process of interview. The transcription of interview was interpreted to analyze what were the causes of the error in using the English preposition. The researcher explained the causes of error based on the respondents answer and the own interpretation.

\section{RESULTS AND DISCUSSION}

The result and discussion of the study are presented in accordance with the three research questions proposed earlier. Based on the findings, there were two major of type of preposition errors found in the students writing. The first one was including into interlingual error, and the second type was the intralingual error. As the first type of prepositiuon error, interlingual means s viewed as a separate linguistic system, clearly different from both the learner's 'native language' (NL) and the 'target language' (TL) being learned, but linked to both NL and TL by interlingual identifications in the perception of the learner (Tarone, 2006:747). This interlingual category constitutes into two category i.e literal translation and features of L1 are transferred to the target language.

As it was found, the error in using preposition was categorized into the transfer of L1 to the target language. It is defined as a similar structural feature; transfer will take place as the feature is seen as viable. Meanwhile, there were no data indicated the literal translation was also found. Errors in features of L1 are transferred to the target language. The use of preposition before the word "there" already means the place the writer meant to. Therefore, additional preposition "in" is not necessarily used in the sentence. This might happen due to the influence of L1 transferred. Therefore, the correct form of them is just using the word "there". As in the following sentences:

(1) When we in come back journey, we looked motorcycle accident. (S10)

(When we come back journey, we looked motorcycle accident) 


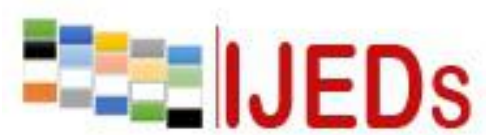

http://ijeds.ppj.unp.ac.id/index.php/IJEDS
International Journal of Educational Dynamics

Vol. 1 No. 1 (pp. 55-68) December 2018

p_ISSN 2655-4852

e_ISSN 2655-5093

(2) It is the reason because in there make an International tariff. (S4)

(It is the reason because they make an International tariff)

The prepositions in those sentences had made them sound like the Indonesian sentences. Therefore, the sentences became incorrect. The total errors for this type were 26 errors.

As the second type of error, the intralingual error had some types i.e omission, addition, misselection of LF preposition, and the redundancy that found in the students' writing. They can be seen in the following explanations: The omission of preposition was one of the type of error in trilingual. This error was including into:

\section{Error in Omission}

\section{a. Omission of "to"}

"To" functions to express the endpoint of path. Therefore, the preposition "to" is needed to if the writer wanted to tell about the place they intended to go. Such as in the following sentences:

At 13:30 we prepare to come back Padang with the train agaru. (S7)

(At 13:30 we prepared to come back to Padang with the train agaru)

b. Omission of "at"

"At" is used before landmarks which indicate points (but not duration) along continuum of time. Specifically, at is used to refer the clock time. Such as in the following sentences:

We went about 12:00 pm from our house and arrived there about 07.00 am. (S9)

(We went at about 12:00 pm from our house and arrived there about $07.00 \mathrm{am}$ )

c. Omission of "in"

"In" is used if the time is in long span. Unless the time the writer meant to is longer than couple of days, then preposition "in" is needed. Such as in the following sentences:

(1) I departured at 07 o'clock morning.(S8)

(I departured at 07 o'clock in the morning)

(2) On my last vacation, when I was holiday in five semester. (S8)

(On my last vacation, when I was in holiday in five semester) 


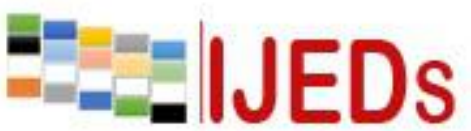

http://ijeds.ppj.unp.ac.id/index.php/IJEDS
International Journal of Educational Dynamics

Vol. 1 No. 1 (pp. 55-68) December 2018

p_ISSN 2655-4852

e_ISSN 2655-5093

d. Omission of "on"

The preposition "on" is needed to express the time; in this situation is the date. Such as in the following sentence:

February, 4th 2016 was my last vacation at Layiang Park, Solok. (S17)

(On February, 4th 2016 was my last vacation at Layiang Park, Solok)

e. Omission of "of".

"In front of" is commonly used to say the thing in before another one. In this case is the thing that located before gate of the zoo. For example:

We decided to go out in front gate of the zoo we saw a tourist. (S20)

(We decided to go out in front of gate of the zoo we saw a tourist)

The total errors for this category were 13 errors.

\section{Error in Addition}

This type of error happened when the unnecessary preposition was added to the sentences. There were some types of this error that found in this research. They are as the following:

a. Addition of "at"

The preposition "at" is inappropriately used due to they seem to be out of the context. They are such the following sentences:

(1) First, when we arrive in there, we saw many beautiful places, at the time at 10:00 am, we felt so hungry and we made a decision to get some foods, we ate fried rice in there and then we continued our destination to the beach. (S14)

(First, when we arrive in there, we saw many beautiful places, at the time 10:00 am, , we felt so hungry and we made a decision to get some foods, we ate fried rice in there and then we continued our destination to the beach.)

(2) At there I really amazed with the crazy scenery. (S11)

(There I really amazed with the crazy scenery)

b. Addition of "to"

The sentence becomes fragment because the use of the preposition "to". It does not show a sentence because the main verb is destructed by the preposition "to". So, to make it becomes the main subject, the preposition "to" needs to be avoided. In this case, 
http://ijeds.ppj.unp.ac.id/index.php/IJEDS

the modals do not need the preposition "to" before the verb one. Therefore, the preposition to is unnecessarily added. They are as in the following sentences:

(1) I went to there by train (S14)

(I went there by train)

(2) We went to there by motorcycle from my boardinghouse. (S3)

(We went there motorcycle from my boardinghouse)

c. Addition of "of"

The preposition "of" seems unnecessarily used in the sentences. In this case, they just unnecessarily added. The preposition "of" had destructed the use of the quantifiers some and many. It is appropriate more if they are followed directly by the nouns. Therefore, they just become many people, some songs, some drinks, some pictures, and some ships. They are in the following sentences:

(1) It has caple card as the transportation to go the Genting Highland because the building of it is in the top of mountain (S8)

(It has caple card as the transportation to go the Genting Highland because the building it is in the top of mountain)

(2) My friends sang some of songs. (S5)

(My friends sang some songs)

d. Addition of "around"

The additions of the preposition "around" to make the sentence destruction. The preposition "around" seems to add unnecessarily. It is such in the following sentence:

We around and see around me. (S6)

(We see around me)

The total errors for this category were 23 errors.

\section{Errors in Misselection of LF preposition}

This type of error happened when the use of preposition is substituted by another one which is incorrect. The users use the incorrect preposition instead the correct one. This types of error were including into: 
http://ijeds.ppj.unp.ac.id/index.php/IJEDS

a. Misselection of "on"

As for days, if a day is named or specified in some ways, use of "on" is normal. Such the sentence a, the writer use to to say a specific day. Thus, it is innormal, the preposition "on" is required in this sentence.

(1)They gave surprise to my birthday party. (S6)

(They gave surprise on my birthday party)

(2) We just sat in the side of beach. (S3)

(We just sat at the side)

b. Misselection of "in"

The preposition "in" is used to the preposition followed by a specifying phares. They are such in the following sentences:

(1) There, the climate is cool especially for the night. (S8)

(There, the climate is cool especially in the night)

(2) At the afternoon, we leave this place and for the next trip we went to waterfall at Lembah Anai. (S9)

(In the afternoon, we leave this place and for the next trip we went to waterfall at Lembah Anai)

c. Misselection of "to"

The preposition "to" is used to various verbs of giving and sending, this is including the verb "communication". In the sentence, the writer did a communication activity in this case is speaking to another person, therefore, in this situation the preposition "to" is used. For example:

She from Amsterdam, I tried to speak with her. (S19)

(She from Amsterdam, I tried to speak to her)

\section{d. Misselection of "at"}

The preposition "at" is used before landmarks which indicate points (but not duration) along continuum of time. Specifically, at is used to refer the clock time. They are such in the following sentences:

(1) In that time, I felt so tired and I went to tent to take a rest. (S6)

(At that time, I felt so tired and I went to tent to take a rest)

(2) I felt shock but I felt so happy in that moment. 
http://ijeds.ppj.unp.ac.id/index.php/IJEDS

(I felt shock but I felt so happy at that moment)

e. Misselection of "by"

The preposition "by" signals something is a means. Therefore, the preposition "by" is more appropriate for this sentence. It shows the mean to indicate the vehicle to use to go to the intended place. For example:

(1) In that time, I felt so tired and I went to tent to take a rest. (S3)

(At that time, I felt so tired and I went to tent to take a rest)

(2) I felt shock but I felt so happy in that moment. (S5)

(I felt shock but I felt so happy at that moment)

f. Misselection of "from"

"From" is used to describe a path in terms of its origin. Therefore, the preposition "from" is more appropriate to show the origin of the news is from the writer's friend. For example:

I know Layiang Park for my friend's account. (S17)

(I know Layiang Park from my friend's account)

The total errors for this category were 27 errors.

\section{Errors in Redundancy}

The unnecessarily over used prepositions came out of the sentence. In this sentence, there is no need to use any preposition to express intended place. Such as in the following sentences:

(1) The first we just set in the side of beach, and enjoyed view, and saw another people who is visited in of beach, then play with my friend, and play sand. (S16) (The first we just set in the side of beach, and enjoyed view, and saw another people who is visited beach, then play with my friend, and play sand)

(2) And then we went around in Pariaman market, my friend bought some skirts and souvenirs. (S7)

(And then we went around Pariaman market, my friend bought some skirts and souvenirs)

The total errors for this category were 4 errors. 


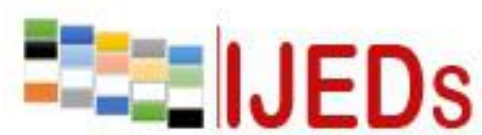

http://ijeds.ppj.unp.ac.id/index.php/IJEDS
International Journal of Educational Dynamics

Vol. 1 No. 1 (pp. 55-68) December 2018

p_ISSN 2655-4852

e_ISSN 2655-5093

\section{The Most Frequent Type of Error in Using Preposition}

As the second research question, the following is the table contains all the types of prepositions' error in the writing test. From the findings above, the types of error in using preposition are 26 numbers of features of L1 are transferred to the target language, 13 omissions, 27 numbers of misselection, and 4 numbers of redundancies.

Among the all the errors in using English preposition, there are 27 numbers of misselection of LF preposition in the case of the use of prepositionby which this type was including into the intralingual error. Therefore, from the data above it can be conclude that the most frequent type of error in using preposition was the intralingual that hold the highest percentage.

\section{The Factors Cause the Error of Using Preposition in Writing Recount Text}

\section{Overgeneralization}

Related to the overgeneralization in using the English preposition, it did not seem to happen in the case of sixth semester students. This one is because the concept among the preposition and other parts of speech are different. Based on the students' responses, there was no indication that the students' felt bias among the English preposition and other language elements. Although it is confusion, however, the case of overgeneralization seemed did not the main factor affecting the errors in using the English preposition. The following is some quotation from the interview on the factors causing the errors in using the preposition.

2. Ignorance of rule restriction

The second point is the next one to be interviewed to the students related to the factors causing the errors in using English preposition. The following quotations are some responses from the students about the questions related to the ignorance of rule restriction.

S1: Kalau preposisi Bahasa Inggris mungkin seperti tadi kadang tercampur dengan conjunction. Sepertinya lupa yang mana preposisi yang mana yang conjunction. Jadi lupa yang mana yang preposisi. Seperti yang "FUNBOY" itu disangka preposisi.

(The English prepositions, just like the previous ones, sometimes get blended by conjuction. So, I forget which one is the preposition. Just like the "FUNBOY" is considered into the preposition.) 


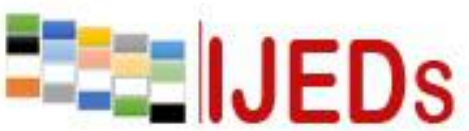

http://ijeds.ppj.unp.ac.id/index.php/IJEDS

S2: Mungkin kalau mengetahui sepenuhnya tidak juga. Kalau dikatakan kurang mengetahui, saya tahu, cuma kalau mengetahui sepenuhnya tidak juga.

(Maybe for knowing all of them, I do not think so. If it is said I less understand, I know a little bit, but for knowing it entirely, I do not think though.)

Some responses above are indicating the the students tend to ignore the rule of preposition. This one is because the rules of preposition are sometimes confusion. Therefore, the rules tend to be ignored since it has various types of rules and preposition is in the level of word can be used without considering

3. Incomplete application of the rules

The incomplete application of the rules seemed not to be the major factor causing the error in using the English preposition. Preposition as one of parts of speech in the level of word do not seem to get the incomplete of application of the rules.

\section{False hypothesis}

The last factor of error in using preposition is the false hypothesis. Related to this point, the preposition is one of words in building the sentences; therefore, the false hypothesis does not seem to happen in using the English preposition. Moreover, about this point, as the students had studied the English preposition, they had known the preposition in English. In fact that they did not use various English preposition in their writing.

Regarding all the findings in this research, Castro in 2003 had also conducted a study on the analysis of prepositional errors. The research was about the error of English preposition on the students writing composition of college students. The result of her work showed that the error in using the English preposition was because of the first language interference in this case is Filipino towards the English preposition. Furthermore about this study, since the preposition is Filipino effect dramatically the English preposition, it had become the main cause why the error occurred in the students writing composition. This fact brings into an understanding that the preposition in one language might affect the preposition in the target language.

The similarity of this study with Castro's is that her study was also in writing composition that showed the error in using preposition of the foreign learners of English. It was sad that the preposition is one of difficult aspects of language that the errors also 


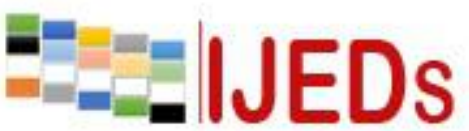

http://ijeds.ppj.unp.ac.id/index.php/IJEDS
International Journal of Educational Dynamics

Vol. 1 No. 1 (pp. 55-68) December 2018

p_ISSN 2655-4852

e ISSN 2655-5093

often happen. The result of the above study does not similar in some ways. Indonesian preposition does not seem to effect the English preposition since it is limited in numbers and variation, besides Indonesian preposition does not have grammatical rule such as the English preposition does. Therefore, the case of interlanguage seems do not appear in this study. While in fact that, this research proved that the main cause of the error in using preposition was due to the intralanguage, it has far difference with the research in the preposition of Filipino.

The same study was also done by Khotaba in 2013. His study was about the error of English preposition of native Arabic graduate students. Since for graduate students the error of using preposition was not expected to happen, however, the errors keep occur in their writing essay. The result of this study showed that the main reason to cause the error in using the English preposition was because of the influence of the first language to the target language. It showed that the errors happened was because of the Arabic preposition, although it has different system with the English one, influence the language users in using the target language preposition.

Having all discussions entire chapter four, in relation to the results of writing tests and interview to the conclusion, the errors of using the preposition might happen in the writings of recount texts done by the students registered in 2013/2014 of academic year due to their low ability of English grammar. Starting from the low numbers errors of using preposition in their writings and the interpretation of the result of the interview had shown that the grammatical problem tend to be the main cause the errors still happen although they had had finished studying all grammar and writing classes.

\section{CONCLUSION}

From all the points that have been stated above, it is found that the types of error in using preposition are omission, misselection, addition, and redundancy in this case it happens within the students' interlanguage. It can be concluded that the students had made some types of errors in using the English preposition in their writing. They had features of L1 were transferred to the target language, omitted, misselected, added and redounded the preposition in the writing of recount text. Therefore, the errors had 


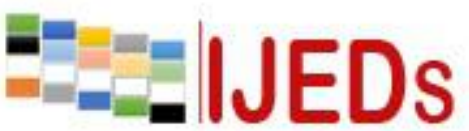

http://ijeds.ppj.unp.ac.id/index.php/IJEDS

\section{International Journal of Educational Dynamics}

Vol. 1 No. 1 (pp. 55-68) December 2018

p_ISSN 2655-4852

e ISSN 2655-5093

happened in using the English preposition. Secondly, the most frequent type of error in using the preposition is the misselection of LF preposition. This one indicates that the students often did not use the correct preposition in their writing. They tend to use incorrect preposition in their essay writing of recount text. Therefore, this fact brings into an understanding that the students had confusion on the English preposition; therefore, they did not use it correctly. The last point about the conclusion is that the cause of the error does not seem to the overgeneralization, incomplete applicant of rule, or the false hypothesis. The ignorance of the rule restriction seems to be the major fact to make the students had produced the error in using the English preposition. It is indicated that they know the English preposition, although not all variation, but they still did the error due to the ignorance of the rule of using preposition.Therefore, their mastery of prepositions related to the function is still low since they tend to add preposition in their sentences that make them incorrect. All of the condition, in this case is the preposition error, may happen due to the students' lack of grammatical mastery.

\section{REFERENCES}

Bhela, B. 1999. Native Language Interference in Learning a Second Language: Exploratory case Studies of Native Language Interference with Target Language Usage. (Online), Vol. 1, No. 1, (https://ehlt.flinders.edu.au/ education/iej/articles/v1n1/bhela/bhela.pdf, retrieved on July, $23^{\text {rd }} 2016$ )

Castro, M. C. S. A. 2003. An Analysis of Prepositional Errors of College Students. (Online), (http://www.litu.tu.ac.th/journal/FLLTCP/Proceeding/ 097.pdf retrieved on November $10^{\text {th }}, 2015$ )

Chong, K. F. 2007. An Analysis of the Prepositional- Error Analysis of Prepositional Errors of Chinese Students. (Online), (http://pustaka2.upsi.edu.my/eprints/163/, retrieved on February $3^{\text {rd }}, 2016$ )

Ghanbari, B et al. 2012. Rating Scales Revisited: EFL Writing Assessment Context of Iran under Scrutiny, (Online), Vol. 2, No. 1, (http://languagetestingasia.com/content/pdf/, retrieved on August $6^{\text {th }}, 2015$ ).

Heydari, P and M. S. Bagheri. 2012. Error Analysis: Sources of L2 Learners' Errors. (Online), Vol. 2 No. 8 (http://www.academypublication.com/ issues/past/tpls/vo102/08/06.pdf, retrieved on May $2^{\text {nd }}, 2016$ )

Khotaba, A. E. 2013. Errors in the Use of Prepositions and Adverb Particles by Arab ESL Speakers: Performance Analysis Perspective. (Online), Vol. 5 No. 1 (http://www.macrothink.org/journal/index.php/ijl/article/download/3310/pdf, retrieved on December $12^{\text {th }}, 2015$ ) 
http://ijeds.ppj.unp.ac.id/index.php/IJEDS

Lindstromberg, S. 2010. English Prepositions Explained. John Benjamins Publishing Company: New York.

Macková, B. L. 2012. A Contrastive Analysis of the Prepositions "To" and "Into". (Online), Department of English and American Studies Masaryk University Faculty of Arts, (http://.is.muni.cz/th/261212/ff_m/MA_thesis.pdf, retrieved on May $\left.4^{\text {th }}, 2015\right)$.

Martinez, S. G. 2006. Journal of Research and Innovation in the Language Classroom: Should We Correct Our Students Errors in L2 Learning?, (Online), (http://www.encuentrojournal.org/textos/16.8.pdf, retrieved on November $12^{\text {th }}$, 2015).

Mutmainna, W. W. 2014. Electronic Journal Literature Faculty of Sam Ratulangi University: "An Error Analysis of Prepositions in Descriptive Texts Made by Students of Madrasah Aliyah Nurul Huda Dowora in Tidore". (Online), Vol: 1, No: 01 (http://ejournal.unsrat.ac.id/index.php/jefs/article/view/4687)

Nonkukhetkhong, K. 2013. Grammatical Error Analysis of the First Year English Major Students, Udon Thani Rajabhat University. (Online). The Asian Conference on Language Learning 2013 Official Conference Proceedings 2013. (http://iafor.org/archives/offprints/acll2013offprints/ACLL2013_0068.pdf)

Nurohmah, I. 2013. An Analysis of Students' Recount Text by Using Systemic Functional Grammar. (Online), retrieved on August 12 $2^{\text {th }}, 2016$

Rajan, S. B. R. et al. 2002. (A Lower Secondary Guide) English in Focus. Pearson Education Asia Pte Ltd: Singapura 